National and Global Petroleum Assessment

\title{
Assessment of Undiscovered Conventional Oil and Gas Resources of the Grand Erg/Ahnet Province, Algeria, 2018
}

Using a geology-based assessment methodology, the U.S. Geological Survey estimated undiscovered, technically recoverable mean resources of 378 million barrels of oil and 7 trillion cubic feet of gas in the Grand Erg/Ahnet Province of Algeria.

\section{Introduction}

The U.S. Geological Survey (USGS) quantitatively assessed the potential for undiscovered, technically recoverable conventional oil and gas resources in the Grand Erg/Ahnet Province (Klett, 2000) of Algeria (fig. 1). North Africa was a north-facing passive continental margin until Late Carboniferous-Permian Hercynian compression reactivated regional fault systems that segmented the passive margin into a mosaic of basins and uplifts (Klett, 2000; Coward and Ries, 2003; Badalini and others, 2009; Eschard and others, 2010). The Timimoun, Sbaa, Ahnet, Oued Mya, Benoud-Melrhir, and Mouydir Basins and the intervening uplifts are within the USGS-defined Grand Erg/Ahnet Province (fig. 1). Silurian and Devonian source rocks deposited during the passive-margin phase are preserved in the basins but were largely eroded from the uplifts during Hercynian compression (Eschard and others, 2010). Variations in the magnitude of subsidence, uplift, and erosion among the basins led to temporal and spatial variations in thermal maturation of the source rocks. In some basins, gas is interpreted to have been generated prior to or during Hercynian compression, whereas in other basins, the source rocks reached the thermal window for oil or gas generation in the Mesozoic (Makhous and others, 1997; Boote and others, 1998; Logan and Duddy, 1998; Makhous and Galushkin, 2003; Eschard and others, 2010; Kaced and Arab, 2012; Jaeger and others, 2017).

\section{Total Petroleum System and Assessment Units}

The USGS defined a Paleozoic Composite Total Petroleum System (TPS) and 11 assessment units (AUs) within this TPS, and 10 of these AUs were quantitatively assessed (table 1; Allal-Idjerane High Conventional Oil and Gas AU was not assessed). The main source rocks for this composite system are the organic-rich lower Silurian Tanezzuft Formation (and equivalent shales; Boote and others, 1998) and Upper Devonian (Frasnian Stage) shales (Lüning and others, 2004). The hydrocarbons generated from these shales were combined into a composite TPS. The geologic model for the Paleozoic Composite TPS is for oil and gas to have been generated from Silurian and Devonian organic-rich shales, with generation possibly ranging from Carboniferous through the Mesozoic. Oil and gas migrated into conventional reservoirs within stratigraphic and structural traps in the basins and migrated updip from the source rocks into conventional reservoirs along the flanks and crests of the uplifts. The uplifts are in a mature stage of exploration, whereas the basins are less mature for conventional resources exploration. Assessment input data are summarized in table 1.

\section{Undiscovered Resources Summary}

The USGS quantitatively assessed conventional oil and gas resources in 10 of the 11 defined AUs (table 2) in the Grand Erg/Ahnet Province of Algeria (Allal-Idjerane High Conventional Oil and Gas AU was not assessed). For undiscovered, technically recoverable conventional oil and gas resources, the mean totals are 378 million barrels of oil (MMBO) with an F95-F5 fractile range from 143 to $801 \mathrm{MMBO}$; 7,032 billion cubic feet of gas (BCFG), or 7 trillion cubic feet of gas, with an F95-F5 fractile range from 2,896 to 13,572 BCFG; and 46 million barrels of natural gas liquids (MMBNGL) with an F95-F5 fractile range from 19 to 90 MMBNGL.

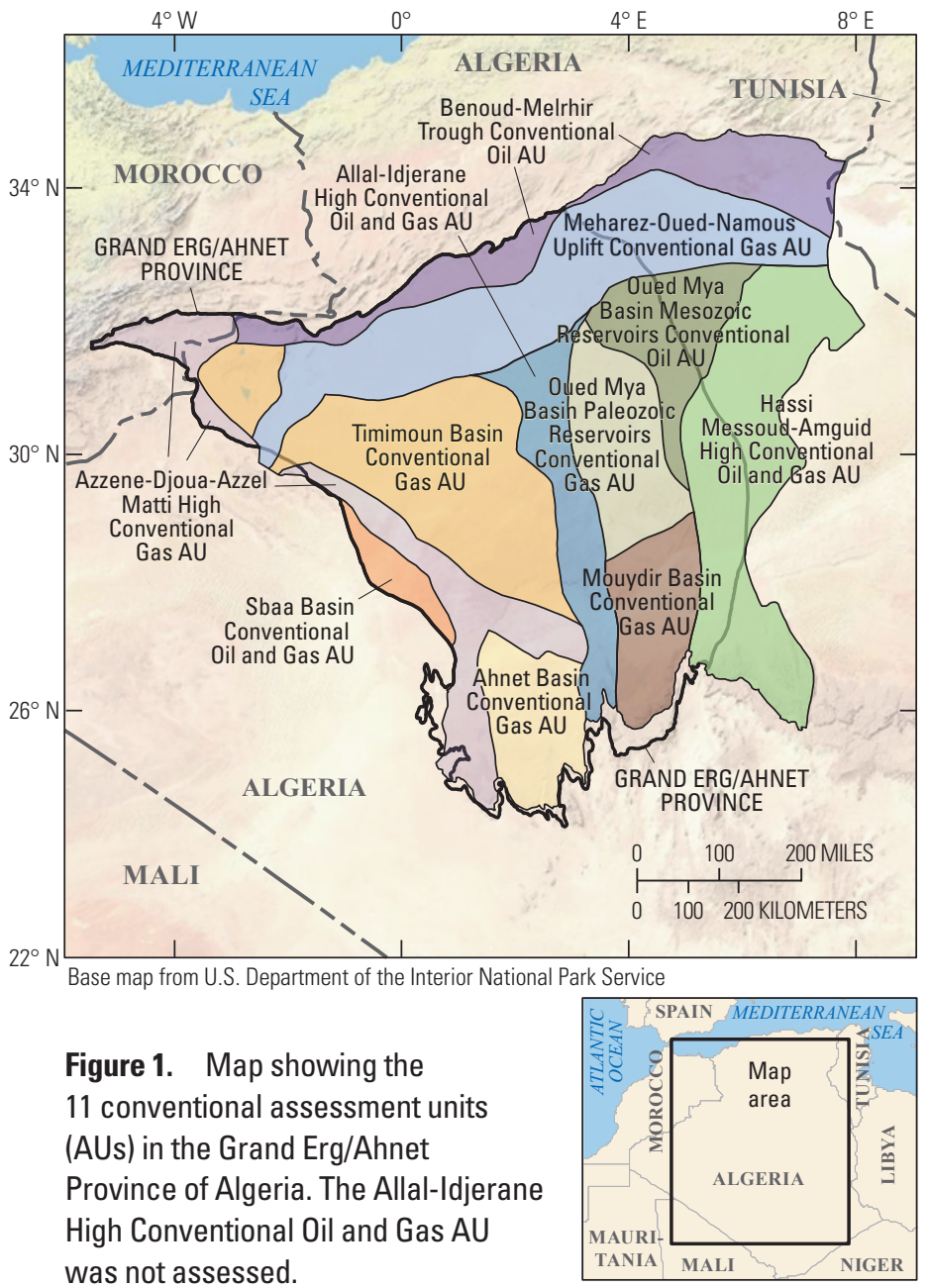

\section{References Cited}

Badalini, G., Redfern, J., and Carr, I.D., 2009, A synthesis of current understanding of the structural evolution of North Africa: Journal of Petroleum Geology, v. 25, no. 3, p. $249-258$

Boote, D.R.D., Clark-Lowes, D.D., and Traut, M.W., 1998, Paleozoic petroleum systems of North Africa, in MacGregor, D.S., Moody, R.T.J., and Clark-Lowes, D.D., eds., Petroleum geology of North Africa: The Geological Society of London, Special Publication No. 132, p. 7-68.

Coward, M.P., and Ries, A.C., 2003, Tectonic development of North African basins, in Arthur, T.J., MacGregor, D.S., and Cameron, N.R., eds., Petroleum geology of AfricaNew themes and developing technologies: The Geological Society of London, Special Publication No. 207, p. 61-83.

Eschard, R., Braik, F., Bekkouche, D., Ben Rahuma, M., Desaubliaux, G., Deschamps, R., and Proust, J.N., 2010, Palaeohighs - Their influence on the North African Palaeozoic petroleum systems, in Vining, B.A., and Pickering, S.C., eds., Petroleum geology-From mature basins to new frontiers-Proceedings of the 7th Petroleum Geology Conference, London, March 30-April 2, 2009: The Geological Society of London, v. 7, p. 707-724. 
Table 1. Key input data for 10 conventional assessment units in the Grand Erg/Ahnet Province of Algeria.

[AU, assessment unit; BCFG, billion cubic feet of gas; MMBO, million barrels of oil. The Allal-Idjerane High Conventional Oil and Gas AU was not assessed. Shading indicates not applicable]

\begin{tabular}{|c|c|c|c|c|c|c|c|c|}
\hline \multirow{2}{*}{$\begin{array}{l}\text { Assessment input data- } \\
\text { Conventional AUs }\end{array}$} & \multicolumn{4}{|c|}{ Timimoun Basin Conventional Gas AU } & \multicolumn{4}{|c|}{ Azzene-Djoua-Azzel Matti High Conventional Gas AU } \\
\hline & Minimum & Median & Maximum & Calculated mean & Minimum & Median & Maximum & Calculated mean \\
\hline Number of gas fields & 1 & 25 & 100 & 27.6 & 1 & 15 & 45 & 16.0 \\
\hline Size of gas fields (BCFG) & 30 & 60 & 1,000 & 85.1 & 30 & 40 & 200 & 45.0 \\
\hline AU probability & 1.0 & & & & 1.0 & & & \\
\hline \multirow{2}{*}{$\begin{array}{l}\text { Assessment input data- } \\
\text { Conventional AUs }\end{array}$} & \multicolumn{4}{|c|}{ Sbaa Basin Conventional Oil and Gas AU } & \multicolumn{4}{|c|}{ Ahnet Basin Conventional Gas AU } \\
\hline & Minimum & Median & Maximum & Calculated mean & Minimum & Median & Maximum & Calculated mean \\
\hline Number of oil fields & 1 & 3 & 6 & 3.1 & & & & \\
\hline Number of gas fields & 1 & 3 & 6 & 3.1 & 1 & 10 & 35 & 10.8 \\
\hline Size of oil fields (MMBO) & 5 & 8 & 40 & 9.1 & & & & \\
\hline Size of gas fields (BCFG) & 30 & 48 & 100 & 49.7 & 30 & 50 & 200 & 55.2 \\
\hline AU probability & 1.0 & & & & 1.0 & & & \\
\hline \multirow{2}{*}{$\begin{array}{l}\text { Assessment input data- } \\
\text { Conventional AUs }\end{array}$} & \multicolumn{4}{|c|}{ Meharez-Oued-Namous Uplift Conventional Gas AU } & \multicolumn{4}{|c|}{$\begin{array}{c}\text { Oued Mya Basin Paleozoic Reservoirs } \\
\text { Conventional Gas AU }\end{array}$} \\
\hline & Minimum & Median & Maximum & Calculated mean & Minimum & Median & Maximum & Calculated mean \\
\hline Number of gas fields & 1 & 10 & 30 & 10.6 & 1 & 15 & 60 & 16.6 \\
\hline Size of gas fields (BCFG) & 30 & 60 & 500 & 74.0 & 30 & 60 & 2,000 & 102.0 \\
\hline AU probability & 1.0 & & & & 1.0 & & & \\
\hline \multirow{2}{*}{$\begin{array}{l}\text { Assessment input data- } \\
\text { Conventional AUs }\end{array}$} & \multicolumn{4}{|c|}{$\begin{array}{l}\text { Oued Mya Basin Mesozoic Reservoirs } \\
\text { Conventional Oil AU }\end{array}$} & \multicolumn{4}{|c|}{ Mouydir Basin Conventional Gas AU } \\
\hline & Minimum & Median & Maximum & Calculated mean & Minimum & Median & Maximum & Calculated mean \\
\hline Number of oil fields & 1 & 10 & 30 & 10.6 & & & & \\
\hline Number of gas fields & & & & & 1 & 5 & 20 & 5.5 \\
\hline Size of oil fields (MMBO) & 5 & 7 & 50 & 8.3 & & & & \\
\hline Size of gas fields (BCFG) & & & & & 30 & 60 & 200 & 65.0 \\
\hline AU probability & 1.0 & & & & 0.5 & & & \\
\hline \multirow{2}{*}{$\begin{array}{l}\text { Assessment input data- } \\
\text { Conventional AUs }\end{array}$} & \multicolumn{4}{|c|}{$\begin{array}{l}\text { Hassi Messoud-Amguid High Conventional Oil } \\
\text { and Gas AU }\end{array}$} & \multicolumn{4}{|c|}{ Benoud-Melrhir Trough Conventional Oil AU } \\
\hline & Minimum & Median & Maximum & Calculated mean & Minimum & Median & Maximum & Calculated mean \\
\hline Number of oil fields & 1 & 10 & 30 & 10.6 & 1 & 5 & 20 & 5.5 \\
\hline Number of gas fields & 1 & 5 & 15 & 5.3 & & & & \\
\hline Size of oil fields (MMBO) & 5 & 8 & 600 & 16.9 & 5 & 10 & 200 & 14.8 \\
\hline Size of gas fields (BCFG) & 30 & 40 & 150 & 43.7 & & & & \\
\hline AU probability & 1.0 & & & & 1.0 & & & \\
\hline
\end{tabular}

\section{Grand Erg/Ahnet} Province Assessment Team

Christopher J. Schenk, Tracey J. Mercier, Marilyn E. Tennyson, Thomas M. Finn, Phuong A. Le, Janet K. Pitman, Ronald M. Drake II, Michael E. Brownfield, Stephanie B. Gaswirth, and Heidi M. Leathers-Miller

\section{For More Information}

Assessment results are also available at the USGS Energy Resources Program website at https://energy.usgs.gov.

Table 2. Results for 10 conventional assessment units in the Grand Erg/Ahnet Province of Algeria.

[MMBO, million barrels of oil; BCFG, billion cubic feet of gas; NGL, natural gas liquids; MMBNGL, million barrels of natural gas liquids. Results shown are fully risked estimates. F95 represents a 95-percent chance of at least the amount tabulated; other fractiles are defined similarly. Fractiles are additive under the assumption of perfect positive correlation. Shading indicates not applicable]

\begin{tabular}{|c|c|c|c|c|c|c|c|c|c|c|c|c|c|c|}
\hline \multirow{3}{*}{$\begin{array}{l}\text { Total petroleum system } \\
\text { and assessment units (AUs) }\end{array}$} & \multirow{3}{*}{$\begin{array}{c}\text { AU } \\
\text { prob- } \\
\text { ability }\end{array}$} & \multirow{3}{*}{$\begin{array}{l}\text { Accu- } \\
\text { mulation } \\
\text { type }\end{array}$} & \multicolumn{12}{|c|}{ Total undiscovered resources } \\
\hline & & & \multicolumn{4}{|c|}{ Oil (MMBO) } & \multicolumn{4}{|c|}{ Gas (BCFG) } & \multicolumn{4}{|c|}{ NGL (MMBNGL) } \\
\hline & & & F95 & F50 & F5 & Mean & F95 & F50 & F5 & Mean & F95 & F50 & F5 & Mean \\
\hline \multicolumn{15}{|c|}{ Paleozoic Composite Total Petroleum System } \\
\hline Timimoun Basin Conventional Gas AU & 1.0 & Gas & & & & & 939 & 2,123 & 4,557 & 2,351 & 3 & 7 & 17 & 8 \\
\hline Azzene-Djoua-Azzel Matti High Conventional Gas AU & 1.0 & Gas & & & & & 375 & 673 & 1,213 & 717 & 2 & 4 & 8 & 4 \\
\hline \multirow{2}{*}{ Sbaa Basin Conventional Oil and Gas AU } & \multirow{2}{*}{1.0} & Oil & 15 & 27 & 45 & 28 & 44 & 80 & 139 & 84 & 0 & 0 & 1 & 0 \\
\hline & & Gas & & & & & 92 & 149 & 221 & 154 & 2 & 3 & 5 & 3 \\
\hline Ahnet Basin Conventional Gas AU & 1.0 & Gas & & & & & 285 & 553 & 1,071 & 599 & 1 & 2 & 4 & 2 \\
\hline Meharez-Oued-Namous Uplift Conventional Gas AU & 1.0 & Gas & & & & & 380 & 735 & 1,376 & 787 & 7 & 14 & 29 & 16 \\
\hline Oued Mya Basin Paleozoic Reservoirs Conventional Gas AU & 1.0 & Gas & & & & & 576 & 1,483 & 3,513 & 1,690 & 2 & 5 & 13 & 6 \\
\hline Oued Mya Basin Mesozoic Reservoirs Conventional Oil AU & 1.0 & Oil & 44 & 83 & 152 & 88 & 39 & 81 & 162 & 88 & 1 & 2 & 3 & 2 \\
\hline Mouydir Basin Conventional Gas AU & 0.5 & Gas & & & & & 0 & 0 & 570 & 179 & 0 & 0 & 2 & 1 \\
\hline \multirow{2}{*}{ Hassi Messoud-Amguid High Conventional Oil and Gas AU } & \multirow[b]{2}{*}{1.0} & Oil & 57 & 146 & 424 & 180 & 38 & 101 & 303 & 126 & 1 & 2 & 6 & 3 \\
\hline & & Gas & & & & & 121 & 218 & 391 & 232 & 0 & 1 & 2 & 1 \\
\hline \begin{tabular}{|l} 
Benoud-Melrhir Trough Conventional Oil AU \\
\end{tabular} & 1.0 & Oil & 27 & 70 & 180 & 82 & 7 & 21 & 56 & 25 & 0 & 0 & 0 & 0 \\
\hline Allal-Idjerane High Conventional Oil and Gas AU & & $\begin{array}{c}\text { Oil } \\
\text { Gas }\end{array}$ & \multicolumn{12}{|c|}{ Not quantitatively assessed } \\
\hline Total undiscovered conventional resources & & & 143 & 326 & 801 & 378 & 2,896 & 6,217 & 13,572 & 7,032 & 19 & 40 & 90 & 46 \\
\hline
\end{tabular}

Jaeger, H., Bechstaedt, T., and Mohr, M., 2017, Multi-phase thermal history of Palaeozoic basins of NW-Africa (Algeria, Morocco) and its impact on hydrocarbon system development [abs.]: American Association of Petroleum Geologists, Search and Discovery Article No. 90313, accessed November 2, 2018, at http://www. searchanddiscovery.com/abstracts/pdf/2018/90313ar/abstracts/ndx jaeger. pdf?q= $\% 2$ BauthorStrip $\% 3$ Ajaeger.

Kaced, M., and Arab, M., 2012, The potential of shale gas plays in Algeria, in 25th World Gas Conference, Kuala Lumpur, Malaysia, June 4-8, 2012, Proceedings: International Gas Union, 18 p., accessed March 15, 2019, at https://www.researchgate.net/ publication/309761788_The_potential_of_shale_gas_plays_in_Algerian.

Klett, T.R., 2000, Total petroleum systems of the Grand Erg/Ahnet Province, Algeria and Morocco-The Tanezzuft-Timimoun, Tanezzuft-Ahnet, Tanezzuft-Sbaa, TanezzuftMouydir, Tanezzuft-Benoud, and Tanezzuft-Bechar/Abadla: U.S. Geological Survey Bulletin 2202-B, 27 p.
Logan, P., and Duddy, I., 1998, An investigation of the thermal history of the Ahnet and Reggane basins, central Algeria, and the consequences for hydrocarbon generation and accumulation, in MacGregor, D.S., Moody, R.T.J., and Clark-Lowes, D.D., eds., Petroleum geology of North Africa: The Geological Society of London, Special Publication No. 132, p. 131-155.

Lüning, S., Wendt, J., Belka, Z., and Kaufmann, B., 2004, Temporal-spatial reconstruction of the early Frasnian (Late Devonian) anoxia in NW Africa-New field data from the Ahnet Basin (Algeria): Sedimentary Geology, v. 163, nos. 3-4, p. 237-264.

Makhous, M., and Galushkin, Y.I., 2003, Burial history and thermal evolution of the southern and western Saharan basins - Synthesis and comparison with the eastern and northern Saharan basins: American Association of Petroleum Geologists Bulletin, v. 87, no. 11, p. 1799-1822

Makhous, M., Galushkin, Y.I., and Lopatin, N., 1997, Burial history and kinetic modeling for hydrocarbon generation, part II-Applying the GALO model to Saharan basins: American Association of Petroleum Geologists Bulletin, v. 81, no. 10, p. 1679-1699. 